\title{
TYPOLOGICAL ANALYSIS OF THE EUROPEAN COURT OF JUSTICE: A GAME THEORETICAL APPROACH TO THE JUDICIARY IN EUROPEAN UNION*
}

\section{Erdem İlker MUTLU*}

"Nay, whoever hath an absolute authority to interpret any written or spoken laws, it is he who is truly the Law-giver to all intents and purposes, and not the person who first wrote or spoke them"1

\section{Abstract:}

This study aims to make a typological analysis on the European Court of Justice. Since the issue has an expansive property, it has been narrowed by keeping it within the limits of a game-theoretical approach. The game is a Bayesian Game and it has three players. The main understanding of the thesis is much concerned with legislature, executive and constitutional juridical bodies. The inter-action of players vice versa effects the structure of strategy profile for each player. The determination of strategy profiles is an outcome for the game. The conclusion is a typology for the European Court of Justice acting as a constitutional court. The main structure of the study built on theories by Thomas Bayes, John F. Nash, John Harsanyi, Joseph H.H. Weiler and Barry Weingast.

Keywords: The European Court of Justice, Game Theory, Typology Analysis, European Community Law.

\section{Özet:}

Tezin konusu Avrupa Topluluğu Adalet Divanı'na oyun kuramsal bir yaklaşımla tipolojik bir tespit yapma üzerine kurulmuştur. Divan'ın hangi

\footnotetext{
" This study is a short synopsis of the $\mathrm{PhD}$ dissertation entitled with the same name and defended on 10 June 2006, Marmara University European Union Institute, Department of European Union Law.

** Dr., Lecturer of European Law, Department of European Union Law, Marmara University European Union Institute.

${ }^{1}$ GRAY, J.C (1909) The Nature and Sources of the Law, Columbia University Pres, New York, p.125,172
} 
tip yargı organı olduğunu, oyun kuraminda ilk oyuncu olan Doğa'nın bize sunmus olduğu ü̧̈ ayrı yargı organı tipinden birini seçmek yoluyla belirlenmiştir. Bu tipler kisaca 'dost', 'düşman' ve 'değişken' olarak adlandırllabilir. Bu tespit için de iç hukuktaki anayasal yargı denetimi benzeri yaptığ yargl işlevi göz önüne altnarak bir değerlendirme yapılmıştır. Oyun kuramı Doğa, Yasama Organı ve Yargı organı olmak üzere $\ddot{u}$ ç tane oyuncudan kurulu olup, bu oyuncular arası muhtemel ilişkileri gösteren bir oyun ağacı da çizilmiştir. Bayes Oyunu denilen bu kuramı Georg Vanberg isimli bilim adamı soyut bir anayasal yargı denetimi oyununa çevirmiş ve bu oyunu da ilk kez Avrupa birliği doğası çerçevesinde kullanilan Avrupa birliğine ait anayasal yapisal elementlerle gözlemleme imkanı bulundu. Avrupa Birliği'nde hukukun gelişimine katkıda bulunan çok önemli bazl davalar ve hukukun genel prensipleri dava tipleriyle birlikte incelendi. Sonuç olarak elde edilen bilgilere göre orijinal uygulamada var olan sistem tipolojisi üzerinde de duruldu ve en son Barry Weingast'in güçler ayrllı̆̆ üzerine çizmiş olduğu bir doğrunun görsel eksikliği bu oyun kuraminın sonuçları da değerlendirilmek yoluyla başka bir şekil oluşturularak çözümlenmiş oldu.

Anahtar Kelimeler: Avrupa Topluluğu Hukuku, Avrupa Topluluğu Adalet Divanı, Oyun Kuramı, Tipoloji Analizi

\section{Introduction}

This study aims to give a short synopsis of the $\mathrm{PhD}$ thesis analyzing the typology of the European Court of Justice (hereinafter the Court) successfully defended on 10 July 2006 and passed with unanimity of the jurors. It contents a game theory ${ }^{2}$ which maintains a focus of the relationship of the Court with the constitutional and political system. Consequently, the constitutional system is determined in a correlation with the conclusion of Barry Weingast's theory on separation of powers (HIX, 2000). The general aim for the research question is to find out "how we can place the Court among other constitutional institutions". This particular issue has a multi-dimensional theoretical approach possibility. One of the previously mentioned dimensions is to make a typology work that connects with legal theory in general and the content of the theory of law of the European Communities. The typology work has advanced the matter as an

\footnotetext{
${ }^{2}$ The set -up where all actions of the actors interactively affect each actor's payoff is called a game. For various definitions of game see Gambarelli \& Owen (2004)
} 
application of a study of vector typology advanced by game theorists on the theory of Thomas Bayes. ${ }^{3}$ Finally, what remained on table was the application of constitutional review game produced by Vanberg over Bayes Theory.

The thesis has three chapters. The first chapter is an introductory study on game theories. The Nash game is defined at first stage. After, the Bayesian game as a 'strategy game' is introduced. There is a special analysis of Bayesian game by John Harsanyi (Harsanyi, 1967) and finally it becomes a constitutional review game by Georg Vanberg (Vanberg 2001). The second chapter introduces the players for constitutional review game. These players are theoretically the nature, legislature and constitutional court. In the realized constitutional review game in the European Union, the second player is the legislature of the EU and the third player is the Court of Justice of the European Communities. The third and final part is the setting up of the game and processing the outcome of the game. The conclusion has become the discussion of a theory related with the separation of powers and relations between judiciary, legislation and execution.

\section{First Chapter and Nash Game:}

The very well-known example of strategy games is the dating game. ${ }^{4}$ The dating game concerns the strategies of two players on the extraction of female player's preferences. Assume a group of students, composed of four girls and six boys, have a possible dating interaction. Only one of the four girls is blonde. However, all the boys in the group are keen to go out with the blonde girl. If the blonde girl is aware of the boys' preference to go out with her, she has two strategies. She may either choose one of the boys, which is not a pleasant condition in the boys' society or she may just ignore all with the superior feeling of being popular. Whenever the boys come

3 The root of Bayesian Game is a conditional probability calculation found by Thomas Bayes, a $18^{\text {th }}$ Century mathematician. The formula of a probability calculation of a member of A through a member of B among all A's and B's such as

$$
\begin{aligned}
& P\left(A_{j}\right) . P\left(B \mid A_{j}\right) \\
& P\left(A_{1} \mid B_{1}\right)= \\
& i=1
\end{aligned} P\left(A_{i}\right) . P\left(B \mid A_{j}\right)
$$

4 The name of 'dating game' may cause confusion. The dating game is an incomplete imperfect information game which provides strategy profiles. The famous tv show dating game is generally a converted version of blind date of the bachelor through the best response to questions asked behind the curtain. 
together to determine a common policy, things change. The common strategy of boys is based on the alternation of counter player's strategy. In order to achieve this, the boys should work on the collapse of superior feeling of being popular on the blonde girl's side. The boys, in a monthly turn, choose only one volunteer in charge to approach the blonde girl, while the others explicitly keep in distance. Therefore, the blonde girl feels no more popular in the eyes of boys, except the one in charge. The blonde girl has no more preferences. Among the previous strategy, the first option which provides the selection among the boys has collapsed.

In this game, the first issue for the players is to set strategy preferences on the wall and rationalize the strategy. For the boys, the issue is to keep all preferences available. The special feature of this game is the extraction of a strategy for the players. The strategy profile arises from the decision making process. Therefore every player needs to make a rational choice and this choice is a product of decision making where the entire of all decisions form a strategy profile for each player.

Before going ahead, it is rather to refer the point of selecting the appropriate type of game. The general classification of games is under two headings: Normal form and extensive form games.

\section{Table 1. Table for categorization of games}

\begin{tabular}{|l|l|l|}
\hline Game Typology: & Normal Form & Extensive Form \\
\hline & NxM Game & Game Tree \\
\hline & Prisoners Dilemma & $\begin{array}{l}\text { Normal Form v } \\
\text { Extensive Form }\end{array}$ \\
\hline & Coordination Games & \\
\cline { 2 - 3 } & Static games & Dynamic games \\
\hline
\end{tabular}

As it is visible in the table, Normal Form games are NxM Game, Prisoners' Dilemma Game, Coordination Games, Static Games. For Strategic (normal) form games, the players move simultaneously. The extensive forma games provide the players an order which is complete for all players. These types of games establish a game tree and generally are dynamic games. 
The Bayes game is an incomplete information game. Incomplete information means the uncertainty of one player on the payoff functions of another player. The incomplete information future of the game renders a shift of paradigm. The probability type of game turns into a strategy type of game. This makes the strategy profile perception for the outcome of the game. Therefore, a strategy profile set works for the determination of a vector determining outcome.

The strategy profiles may change very quickly upon a change in the political climate if the game referred has institutional actors such as a parliament or a constitutional court. This type of a strategy determination between constitutional actors leads us to the constitutional review game. This game is set up by George Vanberg, defining as the nature, the constitutional court and the parliament as the players. The game is set to maintain a typology analysis over the vector determination of strategy profile of the constitutional court. The typology detection is among the types given by nature. The type set is composed of three possible types: Friendly, Assertive and Submissive. Therefore, the nature contents only three possible types of courts which are friendly, submissive and assertive. A court may follow up a very friendly policy with the law maker, so that it does not turn up legislation under constitutional review. Another option is that a court may, be submissive so that it may keep all applications under a very high threshold to turn down legislation. The third option is the court's assertive standing policy. In this case, the court is an assertive character which changes the policy upon the asserted political environment.

The other player is the legislature in Vanberg's constitutional review game. The Legislature has a strategy profile which is changeable between enacting legislation, keeping silent or evading. Consequently, in Vanberg's game the legislature, being one the players, might take a sharp position that provides the evading process as an instrument to keep the control in its hands. However, this type of positioning may cost to lose the public accountability.

Finally, the Court's positioning is crucial in constitutional review. The court may prefer the a position standing very tough against the incompatible legislative acts or may prefer to stand flexible considering the social necessity and easy execution. This two opponent standing points might be balanced whereas the Court takes an assertive rationalist position.

\footnotetext{
${ }^{5}$ Nature, as a player under this game, can be shortly and in its broadest meaning defined as 'up to date account of law and politics in global context'.
} 
At this point, the dissertation takes a point of margin for the relations between legislature and judiciary. The theory of margin is Barry Weingast's separation of powers. Weingast considers the process of legislation as a share of participation on a direct line. The process starts with the initiation of legislature to enact the new law. This new law is introduced to public opinion as the execution exercises a derogative administration using the new law. The original ideal standing point of the legislature on the line is apart from the execution's understanding of law. The ideal standing of the execution is also a matter of effect on the execution of the new law. Therefore as Barry Weingast determined in the figure below, there has to be a point of policy agreement which is the point $\mathrm{X}$. However, this process goes on with a court annulment due to the implementation of the law by execution. Mostly, the administrative acts which seems to be incompatible with the teleological understanding of law is overturned by the Court.

Figure 1. Separation of powers by Weingast (Hix, 2000)

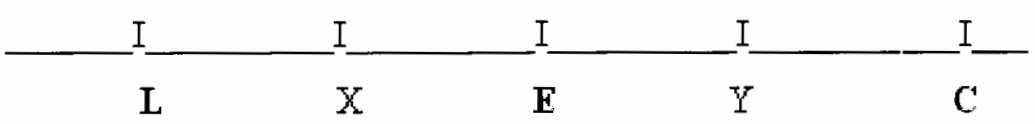

In this diagram

$\mathrm{L}=$ position of legislature

$E=$ position of executive

$\mathrm{C}=$ position of the court

$\mathrm{X}=$ position of a policy agreement between $\mathrm{L}$ and $\mathrm{E}$

$\mathrm{Y}=\mathrm{a}$ position of executive implementation which the Court brought closer to its ideal policy position

There is a strict policy agreement interaction between the legislature and execution connected with another policy agreement interaction between the execution and judiciary. These two derogative policy standings of institutions give shape to the process of legislation. The dissertation offers a solution to the ignorance of judiciary - legislature relations in the theory of Weingast. 
The application of Vanberg's constitutional review game required a court exercising constitutional review. Since the approach of constitutionalism verifies the founding treaties' position like a constitution, the European Court's review of acts' compatibility with the founding treaties makes this court available subject for constitutional review game.

The social and constitutional order in a system of democracy under separation powers gives the courts a social duty that renders only a limited typology. This type set is $\mathrm{Tc}=$ \{Friendly, Submissive, Assertive $\}$ The constitutional order also empowers and legalizes a selection among the above mentioned type set. Therefore the game tree is as follows:

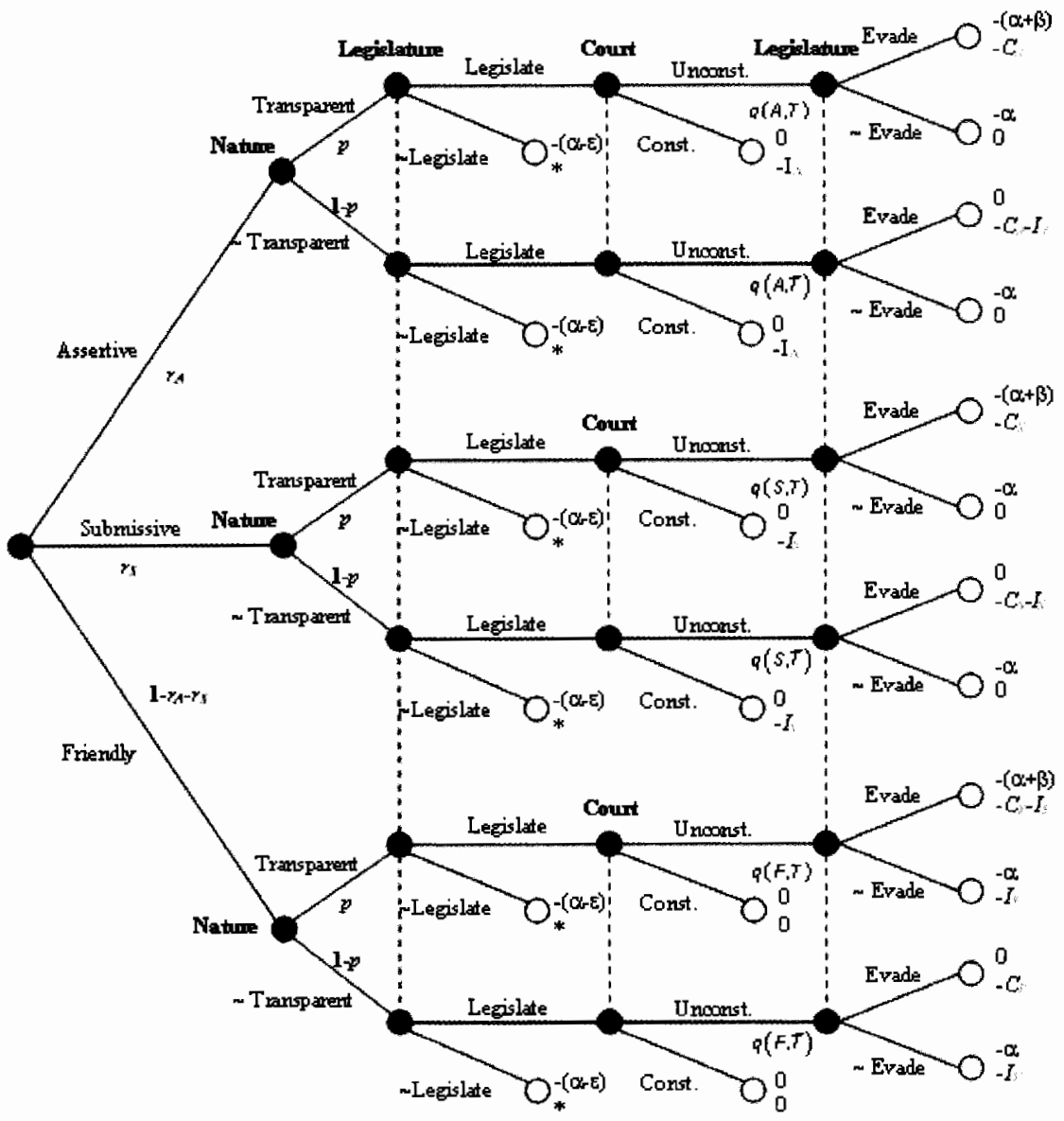


There are determinants other than players. The Brutality of public backlash against the choices of players are among these determinants. Transparency has also an important effect on the available choice of strategies. Since transparency is directly related with the brutality of the public backlash against the act of legislature. Therefore, this type of effect is also taken into consideration in the game tree. The evasion against a court decision which may overturn legislation on the grounds of unconstitutionality is also a possible determinant of the game.

The game tree has three main branches where the friendly, submissive and assertive possibilities are put forth. The values $r_{s}, r_{a}$ and $1-r_{s}-r_{a}$ are the prior beliefs on the typology of the court whether it is submissive, assertive or friendly. A separation for each branch is again the nature's transparent or non-transparent condition. The transparency value is $p$ and nontransparency value is $1-p$. The legislature takes part choosing a strategy to legislate or not to legislate. The value for not legislate is $-(\alpha-\varepsilon)$. If the legislature chooses the option to legislate, the issue is taken before the court for constitutional review. The constitutional review may end up with two possible decisions. The constitutional court may find it unconstitutional or constitutional. If a friendly constitutional court finds the legislation constitutional there is no player payoff. There fore the value for the payoff is 0 . If a submissive or assertive court finds the legislation constitutional there will be issue payoff that can be valued as $I_{s}$ and $I_{a}$ for both courts. The matter of unconstitutionality again brings a set of $q(A, T), q(S, T)$ and $q(F, T)$. The sets are determining the probability threshold of assertive, submissive and friendly courts with transparent environment. The game is over if the constitutional court finds the legislation constitutional. However, there is a last step if the constitutional court finds the legislation unconstitutional. This time legislature may use the power to evade. The evasion may end up to cost institutional and issue payoffs of both legislature and the court in addition with brutality of public backlash.

\section{The Second Chapter: Defining the players of the game}

The model is an applicable model under the conditions where the outcome may test a system typology. According to the model, the legislature may choose a various set of actions to adopt legislation (L) or not to adopt legislation $(\underline{L})$ and to evade the constitutional court's decision (E) or not to evade the constitutional court decision (E). The constitutional court, as another player, has the strategy to find the legislation compatible with constitution (C) or it may find it conflicting with constitution $(\underline{C})$. In constitutional courts account the game ends here and there is no further 
action. The incomplete information around the policy environment and court type produced another parameter for the game which is the transparent (T) environment that requires knowledge of the public of evasion attempt by legislature or non transparent environment $(\underline{T})$ that is suitable for a hidden operation of the legislature.

Applying the model to the system of European Union, the European Court of Justice, the first

The first step forward is to define the players in the political and constitutional environment within the European Union.

The most difficult issue is the definition of nature. The nature is a complementary concept. It includes the nature of law and nature of social order. The concept 'public order' or 'law and order' meets the conservative theatre of 'social order', which is subject to be maintained by law enforcement (Jacobs / Blankenburg / Kritzer / Provine / Sanders, 1996). The law provides an order. Therefore, the ultimate concern is that law is crucial for the maintenance of social order. The nature is used in its 'macro' meaning. The calculation of political environment is not easy. However, in an extensive form game played in genetic engineering, the nature's typology calculation on human genotype is $\mathrm{X}^{23}$ determined by the nature without the participation of any human work.

Another required definition is the legislature in the European Union. Defining the legislature in the quasi-federal structure of the Union is not that easy as it is in a unitary state. In a unitary state, mostly, the legislative power is exclusively given to a parliament constructed by direct elections by citizens. However, in a supranational structure, there might be multi-level representation system ${ }^{6}$. The right to representation is directly related with the question of how to construct the legislature. In the Union, the national agencies and the citizens share it. Consequently, three levels of representation are spoken: the supranational body, national agencies and citizens. However, the representative of supranational body, the Commission, is pacified in rule making. The Council, the representative of national agencies has the core power and the Parliament which represents the citizen of the Union participates in this procedure particularly. Therefore, the Commission, which is the policy initiator, sets the agenda of legislation and proposals in some cases. However, the legislative act starts

\footnotetext{
${ }^{6}$ Another concept derived from the supranational structure on various levels is multilevel governance. The power of governance allocated to multiple levels is in a multi-layer organization.
} 
with the deployment of the Council or the Parliament. This type of interinstitutional allocated legislative power brings the matter of legislative instability in the public arena. The question of legislative instability lies beneath the interaction between various ideal policy standing points of different legislative authorities.

Figure 2. Diagram expressing the instable curves symbolizing the policy exercising space of legislative authorities (for a similar diagram see Hix, 2000)

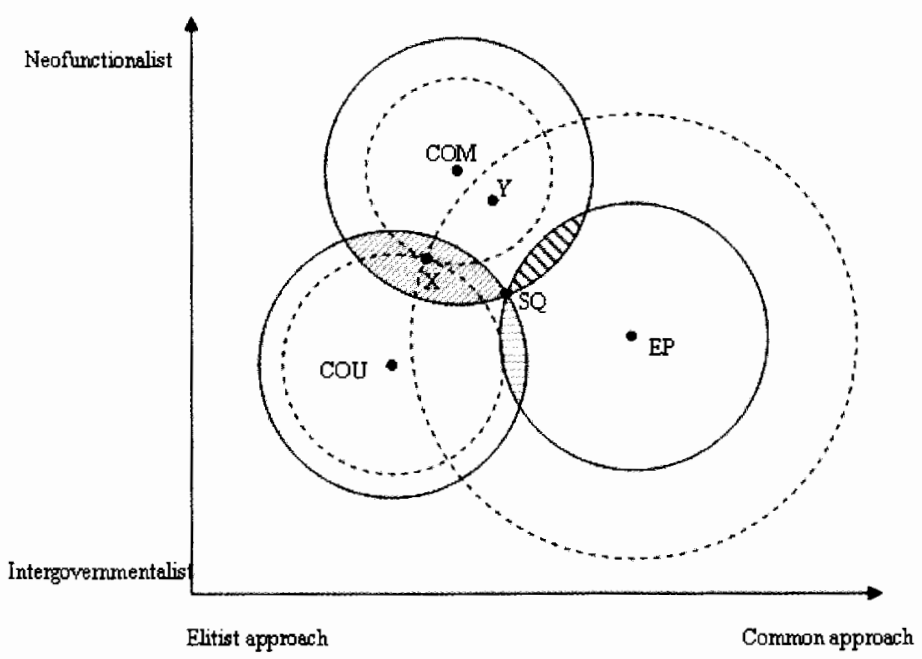

The horizontal line shows the social representation dimension where the institutions keep themselves over the elitist or non-elitist (common) approaches. These approaches are determinants of the tendency by the sources of electors. The vertical line considers the two opponent approaches of intergovernmentalist and neofunctionalist approaches. At this dimension it is no surprise to see the Commission as the closest institution. The Status Quo is the intersection point, the policy agreement between three institutions. The indifference curves may bring the space of action wider, which may extend the wider space intersection point to $\mathrm{X}$.

The definition of the legislature in the EU as a player of constitutional review game may easily be extracted from the diagram above. The core of legislature is a policy compromise between the institutions involved within the legislative process. Thus, the strategy of legislature depends on the interaction between these institutions. 
The final issue is the Court itself. The Court, within the constitutional limits, has a range of action. The game sets an action space for the Court as well as the other players. The Court's action set is as follows:

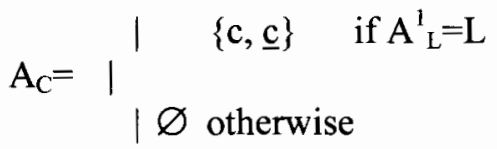

According to the set of action space, if the legislature takes an action to enact a law: $A_{L}^{1} \rightarrow L$,

the constitutional review by the court will take an action from the action space $\{\mathfrak{c}, \underline{\mathrm{c}}\}$ to find the legislation constitutional or unconstitutional. If the legislature does not take an action, the constitutional court has no incentive to take action.

The Constitutional review in the $\mathrm{EU}$ is in two different ways: the preliminary rulings procedure under article 234 and direct action under article 230. The first one is a compliance procedure where the court gives opinion on the interpretation of treaties, the validity and interpretation of acts of the institutions of the Community and the European central Bank and the interpretation of the statutes of the bodies established by an act of Council.

The action space for the Court under 234 is depended on the type space of legislation that can be brought before the Court.

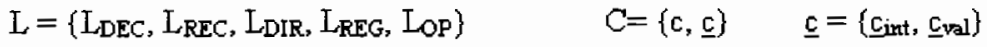

Thus, in this case action set of the Court is

$$
\left\{\underline{C}_{\text {int }}, \underline{G}_{\text {ral }}\right\} \quad \text { if } \mathrm{A}_{\mathrm{I}} \in\left(\mathrm{L}_{\mathrm{DEC}}, \mathrm{L}_{\mathrm{REC}}, \mathrm{L}_{\mathrm{DIR}}, \mathrm{L}_{\mathrm{REG}}, \mathrm{L}_{\mathrm{OP}}\right\} \rightarrow \underline{\mathrm{c}}
$$

$\mathrm{Ac} 234 / 1(\mathrm{~b})=$

$\varnothing$

$$
\mathrm{A}_{\mathrm{L}}^{1} \in\left\{\mathrm{I}_{\mathrm{DEC}}, \mathrm{L}_{\mathrm{REC}}, \mathrm{I}_{\mathrm{DIR}}, \mathrm{I}_{\mathrm{REG}}, \mathrm{L}_{\mathrm{OP}}\right\} \rightarrow \mathrm{c}
$$

There is another type of constitutional jurisdiction which is the direct action under Article 230 of the European Community Treaty. The direct action brought before the court is a case of review the legality of acts adopted jointly by the European Parliament and the Council, of acts of the 
Council, of the Commission, and of the European Central Bank other than recommendations and opinions, and acts of the European Parliament intended to produce legal effects vis-à-vis third parties.

There are three sets of applicants:

$\underline{\mathrm{AP}}_{\mathrm{P}}$

Member States

Council
$\underline{A P}_{S P}$

European Parliament

European Central Bank Legal persons

Commission

In addition the legislation here is $\mathrm{L}=\mathrm{L}_{\mathrm{EU}} ; \mathrm{L}_{\mathrm{EU}}=\left\{\mathrm{L}_{\mathrm{DEC}}, \mathrm{L}_{\mathrm{DIR}}, \mathrm{L}_{\mathrm{REG}}, \mathrm{L}_{\mathrm{REC}}\right.$, $\left.\mathrm{L}_{\mathrm{OP}}\right\}$.

The fact that recommendations and opinions are not subject to review under this article brings the matter as: $\mathrm{f}\left(\mathrm{EC}_{234}\right) \rightarrow\left\{\mathrm{L}_{\mathrm{REC}}, \mathrm{L}_{\mathrm{OP}}\right\} \notin \mathrm{L}$

\section{The third chapter Outcome for the Game}

It is rather to lay out two crucial definitions.

First definition:

Assuming that the legislature's subjective belief at the final information set of the game be designated by $\mathrm{q}(\mathrm{x}, \mathrm{y})$, given that $(\mathrm{x}, \mathrm{y}) \in\{\mathrm{F}, \mathrm{A}, \mathrm{S}\} \times\{\mathrm{T}, \underline{\mathrm{T}}\}$. Consequently, replacing the unknowns $(x, y)$ with elements of information set given above over such a sample of $q(A, \underline{T})$ designates the legislature's subjective belief at the final stage of the game that it is facing an assertive court and the political environment is not transparent.

The second definition:

On the assumption that

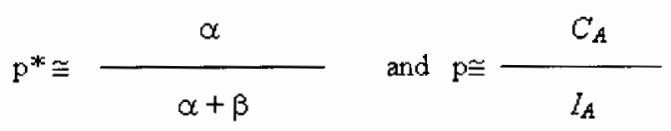

According to this definition, legislative transparency threshold ( $\left.\mathrm{p}^{*}\right)$ is at an equity of legislative resources payoff over a combination of legislative resource payoff and public backlash payoff. The second fragment concerns judicial transparency threshold (p) is a ratio where Assertive court institutional payoff is nominated over the issue payoff of the same type of court as the denominator.

Three different issues related with the outcome of the game are the court reactions which provided the constitutionalism, direct effect and direct 
applicability, general principles. The definition of Treaties under constitutionalized understanding has first been made by Les Verts ${ }^{7}$ trial before the Court. The Court has, for the first time, initiated a constitutional review duty, namely. There is a sharp public backlash which furthered the debate even after 20 years ${ }^{8}$. Therefore, the Court's standing is a strategy choice which effects the prior belief of the legislature.

The perfect Bayesian equilibria (PBE) is a good way of overcoming the problem respectful to the abovementioned assumptions. The perfect Bayesian equilibrium provides four different propositions whereas each proposition is a case study and can be extended to independent discussions. Below, the four propositions are incorporated under four possible different cases of the constitutional review game.

\section{Case 1: Judicial Supremacy}

Art 234/1:

Legislature: $S_{L}=\{\mathrm{L} ; \underline{\mathrm{E}}\} \quad \rightarrow \mathrm{L} \in\left(\mathrm{L}_{\mathrm{EU}}\right)$

Court: $S_{C}=\{\mathrm{c}|\mathrm{F} ; \underline{\mathrm{c}}| \mathrm{A} ; \underline{\mathrm{c}} \mid \mathrm{S}\}$

Art 234 /2-3:

Legislature: $S_{L}=\{\mathrm{L} ; \underline{\mathrm{E}}\} \quad \rightarrow \mathrm{L} \in\left(\mathrm{L}_{\mathrm{N}}\right)$

Court: $S_{C}=\{\mathrm{c}|\mathrm{F} ; \underline{\mathrm{c}}| \mathrm{A} ; \underline{\mathrm{c}} \mid \mathrm{S}\}$

where in both cases the environment is transparent. ( $\mathrm{T}$ is not a variable)

The legislature's beliefs at the final information set are given by

$$
q(A, T)=\frac{r_{A p}}{r_{A}+r_{S}}
$$

\footnotetext{
${ }_{8}^{7}$ Case C- 294/83 Les Verts v. The European Parliament [1986] ECR 1339

8 Schepel comments on the issue in his essay: "The Court has fashioned a constitution of sorts from a relatively unpromising Treaty. On the one hand, 'supremacy' and 'direct effect' have turned the treaty into an instrument that grants rights to private parties, rights that can be asserted to national governments in national courts. On the other hand, 'the rule of law' and the 'institutional balance of powers' have opened up the courtroom for inter-institutional debate where the newly assertive European Parliament can protect its prerogatives vis-à-vis measures adopted by the Council and by the Commission" see SCHEPEL, Harm (2000) Reconstructing Constitutionalization: Law and Politics in the European Court of Justice, Oxford Journal of Legal Studies, Vol. 20 No.3 p.457-468
} 
$q(S, T)=\frac{r_{s} \mathrm{p}}{r_{A}+r_{S}} \quad q(F, T)=0($ Vanberg 2001)

In 'judicial supremacy' case, the Court has a supreme power and accountability, so that the type of the court, without any reference to the transparency in the political environment, may reflect the character of its typology given by nature. Therefore, under these circumstances, a friendly court may not find the statute unconstitutional, but submissive or assertive courts may certainly find it unconstitutional. Therefore, the prior belief for the Court's reaction is the prior belief for the probability of the assertive court multiplied with the transparency threshold for the legislature and divided with the prior belief for the probability of the assertive and submissive courts.

Article 234 has an exclusive master institutional duty to unify the application of European Union Law all over the territories of the Union. By this virtue, all member state agencies have a right to intervene to such a procedure where the Court gives ruling on the understanding of community laws and their compliance with local laws and applications. Therefore, the local legislature has no chance to evade legislation of community law with special reference to direct effect doctrine. Consequently, Article 234/2-3 provides no bargaining process between the local legislature and the Court. The Court has freely takes action among the actions space

$S_{C}=\{\mathrm{c}|\mathrm{F} ; \underline{\mathrm{c}}| \mathrm{A} ; \underline{\mathrm{c}} \mid \mathrm{S}\}$.

\section{Case 2: Autolimitation}

$\alpha-\varepsilon$

For $\mathrm{p} \geq \mathrm{p}^{*}$ and $r_{A}+r_{S}<$

$\alpha$

the following strategy profile represent a Perfect Bayesian Equilibrium of a constitutional review game (Vanberg, 2001)

Legislature: $S_{L}=\{\underline{L} ; \underline{E}\}$

Court: $S_{C}=\{\mathrm{c}|\mathrm{F} ; \underline{\mathrm{c}}| \mathrm{A} ; \underline{\mathrm{c}} \mid \mathrm{S}\}$ 
The legislature's beliefs at the final information set are ${ }^{11}$ given by $q(A, T)=\frac{r_{A} p}{r_{A}+r_{S}}$

$q(A, D)=\frac{r_{A}(1-\mathrm{p})}{r_{A}+r_{S}} \quad q(S, D)=\frac{r_{s} \mathrm{p}}{r_{A}+r_{S}} \quad q(S, D)=\frac{r_{A}(1-\mathrm{p})}{r_{A}+r_{S}}$

$q(F, T)=0$ and $q(F, \underline{T})=0$

Before 2000, there was no document such as the Charter of Fundamental Rights and Freedoms. Because such a written law was lacking, the Court developed the fundamental rights doctrine. Even though the Member States have in their constitutions the community legislature has no incentive to codify fundamental rights. Therefore, the strategy for the legislature was $s=\{L\}$. The final strategy for the legislature is including the first and last step of the game autolimitation $s=\{\underline{L}, \underline{E}\}$. The same issue is true also for general principles of law. Even though there are constitutional provisions over some of the general principles, the legislature has not yet made any attempt to codify a secondary legislation designing principles such as subsidiarity.

\section{Case III Legislative Supremacy:}

Legislature: $S_{L}=\{\mathrm{L} ; \mathrm{E}\}$

Court: $S_{C}=\{\mathrm{c}|\mathrm{F} ; \mathrm{c}| \mathrm{A} ; \mathrm{c} \mid \mathrm{S}\}$

The legislature's beliefs at the final information set are given by

$q(A, T)=r_{A} p$

$q(A, \underline{T})=r_{A}(1-p)$

$q(S, T)=r_{s} p$

$q(S, \underline{T})=r_{A}(1-\mathrm{p})$

$q(F, T)=\left(1-r_{A}-r_{s}\right) p$

$q(F, \underline{D})=\left(1-r_{A}-r_{s}\right)(1-p)$

In this case, the character of equilibrium is legislative supremacy. The legislature has the power so that it can select a strategy profile where it chooses to enact legislation and evade in case of the legislation's turn over by the constitutional court. Therefore, the Strategy space of the constitutional court is rendered to be finding legislation constitutional in every different court typology whether that is friendly, assertive or submissive. In such systems, there are no procedural restraints to the institution using power. 


\section{Case IV: Jousting}

For $\mathrm{p} \leq \mathrm{p}<\mathrm{p}^{*}$ the following strategy profile represents a Perfect Bayesian Equilibrium of a constitutional review game (Vanberg, 2001)

Legislature: $S_{L}=\{\mathrm{L} ; \mathrm{E}\}$

Court: $S_{C}=\{\mathrm{c}|\mathrm{F} ; \underline{\mathrm{c}}| \mathrm{A} ; \mathrm{c} \mid \mathrm{S}\}$

The legislature's beliefs at the final information set are given by

$q(A, T)=\mathrm{p}$

$q(A, \underline{T})=(1-\mathrm{p})$

$q(S, T)=q(S, \underline{T})=q(F, T)=q(F, \underline{T})=0$

In jousting there is a real dwell between the various constitutional actors. The legislature chooses to adopt the legislation. In such a position, the Assertive Court's strategy is to overturn the legislation while the submissive and friendly courts pass it. The assertive Court's strategy within the prior belief of the legislature depends on the transparency of the political environment. If there is transparency, the prior belief over the legislative transparency threshold will be ' $p$ '. Where there is no transparency, the assertive Court's transparency threshold is ' $1-p$ '. There is no expectation in terms of prior belief for the submissive and friendly courts.

\section{Conclusion}

There are three observations related with the outcome of the game and separate conclusions related with the understanding of the dissertation. Firstly, I have to lay out the crucial approach to Weingast's diagram of separation of powers.

A reference to Barry Weingast: the diagram ignores the relationship between judiciary and legislature

The dissertation has re-considered and revised some of the revolutionary step taken by the Court such as the development of the doctrine of direct effect, the development of fundamental rights doctrine and exercising the principles of supremacy and primacy. The purpose was to pick up a court typology. This is necessary for the understanding of judiciary and the relationship of judiciary with political environment. It is achieved by an extensive form game applied in this dissertation.

The finding of the dissertation is that the diagram by Barry Weingast is not sufficient to lay out separation of powers and the relationship between the legislature, execution and the judiciary. The diagram by Weingast is a single dimension which is a direct line starts with and action by legislature and mid points with the ideal policy standing of execution and ends with the 
ideal standing point of judiciary. There are also two compromise points in the two distances between these three points: $x$ (the compromise point between legislature and execution) and $y$ (the compromise point between the execution and court). The dissertation offers a new diagram, which is a triangle where three powers of state is distributed to the three different corners of the triangle. The distances between three powers are assumed to be equal on an idealistic system of separation of powers.

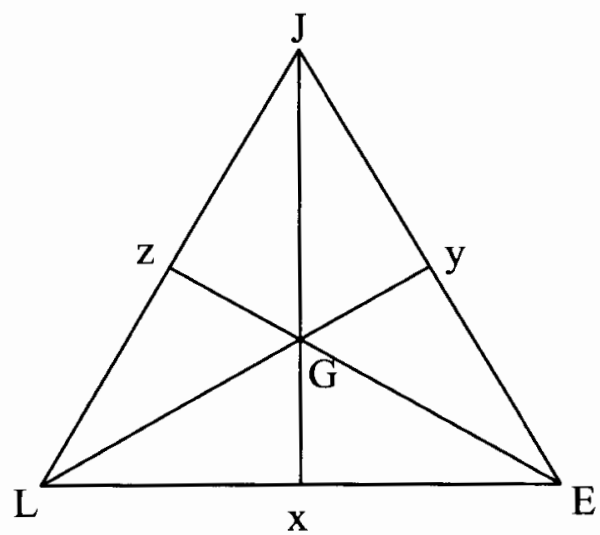

Between these three corners there are mid points where ' $\mathrm{X}$ ' is a compromise point between the legislature and executive ' $y$ ' is a compromise point between executive and judiciary ' $z$ ' is a compromise point between legislature and judiciary.

The point ' $z$ ' that is ignored in the Weingast diagram is a central issue in the constitutional review game. The strategic expectations of legislature and judiciary vice versa on possible counter attacks of 'annulment' and 'evasion' are balanced at the point ' $z$ '.

The ' $G$ ' point, which is the centre of gravity of the triangle, is the hearth of the system. Under the equilateral design, the lines and distances are $|\mathrm{LG}|=$ $|\mathrm{EG}|=|\mathrm{JG}|$ which also means that $|\mathrm{xG}|=|\mathrm{yG}|=|\mathrm{zG}|$ where $|\mathrm{Lx}|=|\mathrm{xE}|$ and $|\mathrm{Ey}|=|\mathrm{y} J|$ and $|\mathrm{Lz}|=|\mathrm{zJ}|$ 


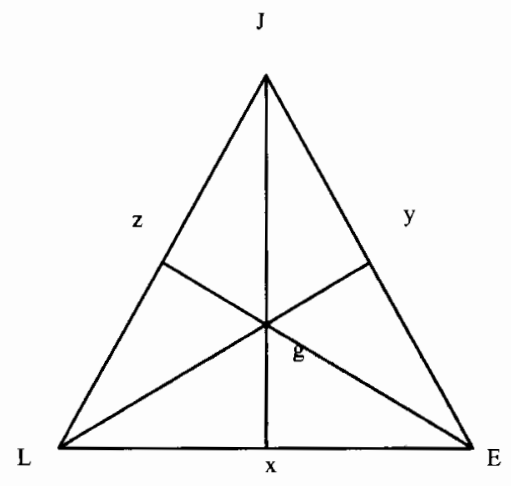

LyE triangle
This type of triangle may change upon the typical variations of the system. Such as the example triangle on the right, the execution may try to use means and methods like 'bureaucratic drift' in order to expand its area of influence. The shaded are in the figure indicates the area of influence of the execution. It is also depended on the presence of a friendly or submissive court, where the behaviour of the court may cause a shift on the standing point of ' $y$ ' on the line $|\mathrm{EJ}|$.

Upon the structure of the constitutional system, the shape of triangle and expansion of shaded areas are subject to change. The dissertation has few more.

\section{Observations and the Court's Judicial Supremacy:}

The first observation is on the effect of transparency in the interinstitutional bargaining between the constitutional court and the legislature vice versa. The transparent political environments which makes easy to publicize legislature's evasion attempt, gives the court an additional accountability and strength. In the positions of autolimitation and judicial supremacy equilibria, both of the hostile court types may avoid implementation of the adopted legislation.

The second observation is on the court's gaining strength and accountability as the public confrontation with the legisiature increases. There is an inverse proportionality between $\alpha$ and $\beta$. Consequently, the legislative transparency threshold increases as the $\beta$ decrease and both hostile courts will overturn the statute as they expect compliance after their decisions. The autolimitation and judicial supremacy equilibria are expected to operate even in less transparent environments. According to some authors (MOLLERS, 2000), this assumption is true for the system of the European Union. The environment in the Union seems to be less transparent. There are various elements, helpful to create a more transparent environment. Among these elements can be counted the preliminary research held at the 
European University Institute, green papers, white papers, action programs exclusively available for some specialists. In addition, the European Parliament has an exclusive type of action. If the European Parliament takes earlier steps of legislative procedures, it may publicize them for creating a more transparent legislative procedure.

The third observation is on the proportionality between the Court's power and the increasing importance of the issue under review. At this point, there is an inverse proportionality. The court's power to overturn the issue is weaker, as the importance of the issue increases. The legislative transparency threshold increases as the $\alpha$ increases. Consequently, it is evident that the political ventures of the issue under review increase for the legislature. The submissive court is likely to uphold the legislation while the assertive court is expected to be evaded by the legislature.

It is evident that there are not only legal and constitutional factors determining the type space of a court. The political environment that also contents the question of transparency and public support is another effective factor, for instance.

Considering propositions 1 and 2, there is no need to act in strategic behavior for the court, while there is no risk of non-compliance. In this case, the public back up for the court is strong ( $\beta$ is large) and the threat of public censure is considerable while the legislative reactions to a court decision are easily to be monitored by citizens ( $p$ is large). Otherwise is the centralization of the question on the problem of compliance. Recalling the cases 3 and 4, the Court may prefer to overturn the legislation.

The deepest issue within these observations is the issue of transparency. Three different dimensions of transparency should be re-considered. The first one is the availability of transparency within the design of institutions having legislative power. The institutional design must be appropriate to give citizens the opportunity to 'monitor the legislative act'. Vanberg compares classical parliamentary system with presidential system and concludes that a presidential system is more transparent due to the fact that dual executive has a balance between counter powers restraining each other.

In the institutional and constitutional design of the European Union legislative powers are set up under a procedural balance. The commission, holding the label of the core executive has a minor space in legislative procedure. Moreover, the two big executive and elite brothers of legislative procedure have a monitoring system in interactive process: the comitology. 
Committees of Member State representatives assist or supervise the Commission in its implementation of the European Union legislation.

Another dimension of the transparency is constituted by exogenic issues within the scope of some specific decisions. With regard to the Court's rulings in some specific areas, there may be a public attitude giving more attention to some rulings when compared with average public attention to court rulings. In some cases, non-governmental organizations, interest groups and media may act as 'watchdogs' over the Court's anticipated ruling.

Type of Court: recalling activism?

Judicial activism is deemed as a dangerous phenomenon in many legal systems. Activism is not an interpretation method but far more than contextual or teleological interpretation searching even travaux preporatoir.

The observation of this study is that the European Court of Justice remains a hostile court. This type of a court generally takes an activist position and upholds or overturns legislation. Nevertheless, here again the judicial transparency threshold takes place. Judiciary regards the institutional payoff while the issue payoff is not a prevailing issue. Therefore, under these circumstances, the Court will prefer to keep in autolimitation.

Contrarily, issue payoff might be extremely high in certain cases. The issue may affect even the constitutional element of a political system. Another point, a secondary nature, may not even be thought of. Schepel expresses such a position as follows:

"The rise and fall of the ECJ's activism in Dehousse's version is an elegant tale of quasi-natural evolution of judicial constitution building"

\section{References:}

Gambarelli, Gianfranco and Owen, Guillermo (2004). Theory and Decision. Netherlands: Kluwer Academic.

Harsanyi, John C (1967). "Games with Incomplete Information Played by Bayesian Players I II III". Journal of Management Science, Vol 14.

Hix, Simon (2000). The political System of Europe. London: Palgrave. 
Jakob, Herbert / Blankenburg, Erhard / Kritzer, Herbert M./ Provine, Doris Marie \& Sanders, Joseph ( 1996 ). Courts, Law \&Politics in Comparative Perspective. New Haven/London: Yale University Press.

Nash, John Forbes (1996). "The Bargaining Problem", Econometrica 18 in Essays on Game Theory. Vermount (US): Edgar Elgar Publishing.

Schepel, Harm and Blankenburg, Erhard (2001). "Mobilizing the European Court of Justice" in Weiler, JHH and De Burca G. (Eds). The European Court of Justice.

Vanberg, George (2001). "Legislative-Judicial Relations: A GameTheoretic Approach to Constitutional Review". American Journal of Political Science, Vol.45. April, No. 2. 


\section{Table of Game Theoretical Notation}

$\beta \quad$ a measure of the brutality of public backlash

$\alpha$ issue payoff for legislature institutional payoff for legislature

$C$ institutional payoff for the court in constitutional review game

$I \quad$ issue payoff for the court in constitutional review game

$C_{E C J} \quad$ institutional payoff for the European Court of Justice

$I_{E C J} \quad$ issue payoff for the European Court of Justice

$P \quad$ transparency threshold for legislature

$P^{*} \quad$ transparency threshold for the Court

$T_{C} \quad$ type space of Court

$T_{C}{ }^{E U} \quad$ type space of the Court in the EU

$c \quad$ court's decision finding the bill constitutional

$\underline{C} \quad$ court's decision finding the bill unconstitutional

$c_{V A L} \quad$ unconstitutionality on grounds of 'validity'

$c_{I N T} \quad$ unconstitutionality on grounds of 'interpretation'

$c_{A P P}$ unconstitutionality on grounds of 'applicability'

$T \quad$ transparent

$\underline{T} \quad$ not transparent

E evade

$\underline{E} \quad$ not evade

$L \quad$ legislate

$\underline{L} \quad$ not legislate

$S_{C} \quad$ strategy space of court

$A_{C} \quad$ action space of court

$A^{l}{ }_{L}$

$A^{2}{ }_{L}$

action of the legislature to pass the bill no 1

action of the legislature to pass the bill no 2

$P(.$.$) \quad probability of ..$

$r .$.

$\varnothing$

prior belief for the probability of..

empty set

$\epsilon$

is an element of 